\title{
Korekta ust metodą sześciu kroków
}

\author{
Lip correction using the six-step method
}

\author{
${ }^{1}$ Gabinet stomatologiczny, Szczecin \\ Dental practice, Szczecin, Poland \\ ${ }^{2}$ Zakład Stomatologii Zintegrowanej, Pomorski Uniwersytet Medyczny w Szczecinie \\ Department of Interdisciplinary Dentistry, Pomeranian Medical University, Szczecin, Poland
}

DOI: http://dx.doi.org/10.20883/df.2021.2

\begin{abstract}
STRESZCZENIE
Wstęp. W kulturze europejskiej odpowiedni kształt ust jest ważnym atrybutem atrakcyjności. Oczy i usta nadają twarzy charakter, a wiele osób zwraca na nie szczególną uwagę, bo zdradzają informacje niewerbalne. Z upływem czasu usta, podobnie jak skóra, wrażliwe na czynniki zewnętrzne oraz wewnętrzne zmieniają swój wygląd. Potrzeby korekcyjne pacjenta mogą wahać się od subtelnego wzmocnienia i tak już odpowiedniego kształtu i objętości do bardziej kompleksowego modelowania, w tym korekty zmarszczek, a także niwelowania defektów lub asymetrii.

Cel pracy. Głównym celem pracy jest przybliżenie podstawowych zasad wykonywania zabiegu korekty ust.

Materiał i metody. Zabiegom poddano dwie kobiety w różnym wieku. Zabieg przeprowadzono po raz pierwszy. Do leczenia wykorzystano kwas hialuronowy średniej gęstości $23 \mathrm{mg} / \mathrm{ml}$ z lidokainą 0,3\%.

Wyniki. U obu pacjentek uzyskano efekt odmłodzenia ust, stały się one pełniejsze i bardziej wyraźne, poprawiły się proporcje warg.

Wnioski. 1. Zabiegi z zastosowaniem kwasu hialuronowego są skuteczną metodą korekty kształtu ust. 2. Techniką sześciu kroków można bezpiecznie wykonywać zabiegi w obrębie szeregu struktur anatomicznych, w tym w zakresie filtrum, łuku Kupidyna, czerwieni wargowej, granicy czerwieni wargowej, kątów ust oraz kolumn rynienki podnosowej. 3. Zabiegi te nie wymagają specjalnego przygotowania pacjenta, są dobrze tolerowane, pozwalają uzyskać naturalny, natychmiastowy efekt i nie wymagają okresu rekonwalescencji.
\end{abstract}

Słowa kluczowe: wargi, korekta ust, kwas hialuronowy.

\section{ABSTRACT}

Introduction. In European culture, the right shape of the lips is an important attribute of attractiveness. The eyes and lips give character to the face, and many people pay special attention to them because they reveal non-verbal information. Over time, lips, like skin, which are sensitive to external and internal factors, change their appearance. The patient's corrective needs can range from a subtle enhancement of the already appropriate shape and volume to more comprehensive modeling, including the correction of wrinkles, as well as eliminating defects or asymmetries.

Aim of the study. The main purpose of the study is to present the basic principles of lip correction surgery.

Material and methods. Two women of different ages were subjected to the treatments. The procedure was performed for the first time. Hyaluronic acid of average density $23 \mathrm{mg} / \mathrm{ml}$ with lidocaine $0.3 \%$ was used for the treatment.

Results. Both patients had the effect of rejuvenating the lips, they became fuller and clearer, lip proportions improved. Conclusions. 1. Treatments with the use of hyaluronic acid are an effective method of correcting the shape of the lips. 2. The six-step technique can safely perform treatments on a range of anatomical structures, including the filterium, Cupid's arch, the labia, the border of the labial red, the angles of the mouth, and the columns of the nasal trough. 3. These treatments do not require special preparation of the patient, are well tolerated, allow for a natural, immediate effect and do not require a convalescence period.

Keywords: lips, lip correction, hyaluronic acid.

\section{Wstęp}

W kulturze europejskiej odpowiedni kształt ust jest ważnym atrybutem atrakcyjności. Oczy i usta nadają twarzy charakter, a wiele osób zwraca na nie szczególną uwagę, bo zdradzają informacje niewerbalne. Kształt i kolor ust są indywidualną cechą i trudno znaleźć dwie identycznie wykrojone wargi. Już od wieków kobiety chętnie podkreślały usta lub starały się skorygować ich kontury, stosując różne triki. Pełne usta zawsze kojarzyły się 
z młodością i pięknem. Udowodniono, iż atrakcyjni ludzie są postrzegani jako bardziej przyjaźni, bardziej inteligentni i bardziej kompetentni społecznie. Stąd też wiele kobiet decyduje się na zabiegi z zakresu medycyny estetycznej lub chirurgii plastycznej, których celem jest nadanie wargom odpowiedniego kształtu oraz wielkości [1]. Lekarz dentysta $\mathrm{w}$ trakcie leczenia stomatologicznego i rehabilitacji protetycznej powinien zwrócić także uwagę na usta, gdyż stanowią one oprawę dla zębów jak rama dla obrazu. Efekt poprawy wyglądu uzębienia będzie bardziej spektakularny, jeśli wargi będą miały właściwe proporcje, objętość oraz nawilżenie.

\section{"Złote proporcje" warg}

Zarówno objętość jak i wysokość pionowa cynobru wargi górnej i dolnej powinna mieścić się w ramach stosunku - 1:1,618, czyli klasycznej „złotej proporcji" DaVinci. W wymiarze pionowym określamy stosunek wysokości wargi dolnej do górnej. Stosunek objętości wargi dolnej do górnej określamy w widoku bocznym: jeśli z punktu subnasale zostanie narysowana linia prosta do punktu pogonion, górna warga powinna wystawać 3,5 mm przed linią i dolna warga powinna wystawać $2,2 \mathrm{~mm}$; górna warga powinna wystawać nieco więcej, niż dolna warga - w proporcji około 1,6:1 [2].

\section{Starzenie się warg}

Zwiotczenie skóry związane ze starzeniem się powoduje wydłużenie skórnej części wargi, wraz ze skróceniem widocznej powierzchni błony śluzowej i ogólnym spłaszczeniem wargi. Granica cynobrowa odwraca się, powodując zmniejszenie napięcia warg. Usta w podeszłym wieku przybierają dwuwymiarowy, spłaszczony wygląd w porównaniu z pełniejszą, młodzieńczą wargą. Dolna warga jest mniej cienka, głównie dlatego, że z czasem jest mniej podatna na kurczenie się. Te efekty grawitacji połączone z utratą objętości warg i podparcia mogą spowodować opadnięcie wargi pionowo [3].

Uwarunkowania genetyczne, ekspozycja na słońce, palenie tytoniu i powtarzalne ściskanie mięśnia okrężnego ust tworzą kątowe, promieniowe i pionowe "linie krwawienia pomadki". Grawitacja, osteoporoza, zmiany zębowe, resorpcja kości szczęki i żuchwy i dalsza utrata objętości tkanek miękkich w okolicach ustnych powodują, że obracają się one $w$ dół $z$ wieczną zmarszczką. Starzenie się twarzy, zwiotczenie policzków powoduje powstawanie pionowych linii żuchwowych („,marionetka"), które rozciągają się w dół od kącików ust do żuchwy.

\section{Metody korekcji ust}

Z upływem czasu usta, podobnie jak skóra, wrażliwe na czynniki zewnętrzne oraz wewnętrzne zmieniają swój wygląd. Zaburzenie proporcji twarzy może nastąpić również w wyniku defektów wrodzonych, urazów lub chorób [4]. Dostępnych jest wiele produktów do korekcji ust, w tym trwałych i nietrwałych jak wypełniacze skórne, implanty, neurotoksyny, lasery i mikropigmentacja. Półtrwałe wypełniacze skórne - takie jak hydroksyapatyt wapnia i kwas polimlekowy - nie są preferowane do powiększania warg, ponieważ mają zwiększone ryzyko nieregularności i powstawania guzków. Chirurgiczne implanty warg i autologiczny transfer tłuszczu są używane bardzo rzadko [5]. Najpopularniejszymi i najczęściej używanymi są wypełniacze na bazie kwasu hialuronowego. Wypełniacze kwasu hialuronowego mogą być również stosowane w leczeniu pooperacyjnym, asymetrii oraz blizn pozapalnych na wargach. Powiększanie ust za pomocą wypełniaczy skórnych z kwasem hialuronowym jest procedurą minimalnie inwazyjną, która zyskała na popularności przez ostatnie lata. Nie wymaga testu skórnego, jest odwracalna dzięki hialuronidazie. Istnieje wiele technik zalecanych do modelowania ust, jednak nie ma jednej recepty na idealną wargę [6]. Celem uzyskania poprawy proporcji dolnego piętra twarzy można wykorzystać podstawowy szablon sześciu kroków. W celu pełnego efektu odmłodzenia, zabiegi można poszerzyć iniekcją środków neuromodulujących i frakcyjnym laserowym odnawianiem skóry. Pamiętając przy tym, iż w pierwszej kolejności wykonujemy zabiegi wysokoenergetyczne, w przeciwnym razie wysoka temperatura może powodować szybsze rozpuszczenie materiałów użytych do korekcji [7].

Potrzeby korekcyjne pacjenta mogą wahać się od subtelnego wzmocnienia i tak już odpowiedniego kształtu i objętości do bardziej kompleksowego modelowania, w tym korekty zmarszczek. Z uwagi na ekspresję warg, dodając wypełniacz, jednoczesne utrzymywanie naturalnego wyglądu podczas ruchu i odpoczynku jest technicznie trudne. Wargi są również gęsto unaczynione i podatne na reakcje $w$ miejscu wstrzyknięcia, takie jak obrzęk i zasinienie. Kompleksowe zrozumienie cech anatomicznych i odpowiednich technik jest ważną podstawową informacją dla osoby podającej [8]. Podobnie wybór materiału wypełniającego jest ważny, ponieważ zapewnia powodzenie zastosowanych technik iniekcji. Skutecznymi wypełniaczami do korekcji warg są żele drobnocząsteczkowe z kwasem hialuronowym. Rozmiar cząstek 
i właściwości reologiczne tych żeli są dobrze dostosowane do ograniczeń cienkich igieł, a powierzchowne techniki wstrzykiwania są wymagane do uwydatnienia warg [9]. Kwas hialuronowy (KH) jest naturalnie występującym liniowym polisacharydem złożonym z powtarzającej się jednostki disacharydowej kwasu d-glukuronowego i N-acetylod-glukozaminy. Powszechne stosowanie kwasu hialuronowego wynika $z$ jego biokompatybilności i łatwości przetwarzania. Jest podstawowym składnikiem macierzy zewnątrzkomórkowej tkanki łącznej. Z wiekiem ilość kwasu hialuronowego w organizmie zmniejsza się. Naturalny kwas hialuronowy ma okres półtrwania do $48 \mathrm{~h}$, co ogranicza jego zastosowanie jako wypełniacza [10].

Poprzez sieciowanie (ang. cross-linking) następuje chemiczne łączenie łańcuchów kwasu hialuronowego ze sobą, co czyni go bardziej odpornym na działanie naturalnej hialuronidazy występującej w tkankach. Proces ten pozwala zatem na uzyskanie takiej struktury kwasu, którą organizm usuwa znacznie wolniej - nie w ciągu kilku dni, ale kilku do kilkunastu miesięcy. Modyfikacja żelu może powodować tworzenie różnej wielkości cząstek przeznaczonych do różnych części twarzy [11].

Sieciowanie z jednej strony chroni cząsteczki kwasu hialuronowego przed rozłożeniem, a z drugiej - nadaje mu specyficzne właściwości fizykochemiczne: lepkość, gęstość, odkształcalność czy zdolność unoszenia tkanek. Kwas hialuronowy wykazuje dużą zdolność łączenia cząstek wody poprzez ujemne naładowanie elektromagnetyczne [12].

Zmodyfikowany kwas jest silnie hydrofilowy i potrafi wchłonąć 1000-krotność swojej objętości, posiada też duże właściwości reologiczne. Klinicznie oznacza to, że można umieścić go w odpowiednim miejscu. Obecnie wielu producentów posiada w swej ofercie preparaty KH o różnej gęstości, często w połączeniu ze środkami miejscowo znieczulającymi. Dzięki temu możemy dobierać materiał adekwatnie do potrzeb, w tym do struktury, która ma zostać wypełniona [1]. Oprócz fizycznego wypełnienia tkanki, kwas hialuronowy stymuluje także tworzenie się własnego kolagenu. Sam bodziec iniekcji (nakłucie skóry) oraz mechaniczne oddziaływanie preparatu podanego do skóry pobudza fibroblasty do produkcji kolagenu [5].

Technika 6-etapowa korekcji ust obejmuje podanie około 12 zastrzyków - około $0,1 \mathrm{~cm}^{3} \mathrm{KH}$ na iniekcję-umieszczonewstrategicznychlokalizacjach w obrębie górnej i dolnej wargi. Nie wszystkie obszary muszą wymagać wypełnienia, a inne mogą wymagać nieco więcej lub mniej niż $0,1 \mathrm{~cm}^{3}$. Najpierw zajmujemy się górną wargą, aby jej obrzęk nie uniemożliwił utrzymania prawidłowych proporcji anatomicznych między górną a dolną wargą.

Pierwszy krok stanowi podkreślenie kolumn filtrum. Filtrum, czyli rynienka podnosowa jest krótkim i płytkim zagłębieniem biegnącym od przegrody nosa do wargi górnej. Jego stelaż zapobiega wywijaniu się ust w kierunku nosa. Rzeźbione kolumny filtrum są dziś modne. $Z$ wiekiem te dobrze zdefiniowane słupy zanikają, co prowadzi do spłaszczenia, nieatrakcyjności górnej wargi. Jeśli kolumny filtrum zostały całkowicie zatarte, to konieczne jest, aby je ponownie utworzyć. Osiąga się to powierzchownie przez pionowy depozyt wypełniacza do każdej kolumny filtrum. Ważne jest, aby zdawać sobie sprawę, że kolumny filtrum nie są równoległe do siebie, ale raczej tworzą odwrócone "V", które zwęża się, gdy zbliża się do progów nozdrzy. Około 0,1 $\mathrm{cm}^{3}$ wypełniacza KH należy wstrzyknąć do każdej kolumny filtrum. Igłę wprowadza się w granicę czerwieni warg, w punkt szczytowy łuku Kupidyna. Uszczypnięcie skóry niedominującą ręką podczas wypełniania wstecznego kolumn filtrum zmniejsza dyskomfort, utrzymuje wypełniacz w wypukłości i zapobiega jego rozlewaniu się na boki. Ściśnięcie po wstrzyknięciu pomaga $w$ dalszym formowaniu wypełniacza w celu trwałego zdefiniowania tych kolumn. Po zakończeniu wstrzyknięć do kolumn filtrum zauważa się natychmiastową definicję dołka filtrum i poprawę łuku Kupidyna. Należy oszczędnie dozować wypełniacz, aby nie doprowadzić do nienaturalnych efektów.

Kolejnym etapem jest podkreślenie łuku Kupidyna. Łuk Kupidyna - jest to linia o trójkątnym lub owalnym kształcie, znajdująca się pośrodku górnej wargi ust i stanowi dolną podstawę filtrum. Rozdziela ona wargę górną na dwie części - prawą i lewą. W zależności od stopnia rozwartości jego kąta nadaje on specyficzny wygląd czerwieni wargowej, czyli tzw. serduszka. Puchaty, łukowaty wygląd środkowej części górnej wargi jest dziś uważany za pożądany i bardzo modny. Końcówkę igły należy umieścić u podstawy kolumny filtrum (w miejscu połączenia cynobru ze skórą) i przejść do połączenia cynobru z błoną śluzową („linia mokra”). Wstrzyknąć cienką nitkę wypełniacza o pojemności $0,1 \mathrm{~cm}^{3} \mathrm{w}$ sposób wsteczny. Ta nić wypełniacza działa jak rozpórka przednio-tylna, wspierająca środkową część górnej wargi.

Krok trzeci to zdefiniowanie połączenia cynobrowo-skórnego w środkowej części podjednostki bocznej. Górna warga jest podzielona poprzecznie na część środkową i boczną. Przyśrodkowa podjednostka górnej wargi rozciąga się od linii środ- 
kowej do kolumny filtrum; boczna podjednostka rozciąga się od kolumny filtrum do jamy ustnej i fałdu nosowo-wargowego. Podany tutaj będzie ok. $0,1 \mathrm{~cm}^{3} \mathrm{KH}$ bocznie z podstawy kolumny filtrum, wzdłuż połączenia cynobrowo-skórnego, około połowy drogi do jamy ustnej. Na tym etapie ważne jest, aby nie powiększać połączenia cynobrowo-skórnego wzdłuż całej części bocznej, ale tylko w jej początkowym odcinku za filtrum. Nie powinno się powiększać połączenia cynobrowoskórnego w środkowej podjednostce, ponieważ spowoduje to zatarcie ukłonu Kupidyna i powstanie tzw. „kaczych ust”.

Następnym etapem jest podkreślenie uwypukleń bocznych na dolnej wardze. W tym celu najlepiej poprosić pacjenta o wywrócenie dolnej wargi. Należy zostawić około $\sim 0,1 \mathrm{~cm}^{3}$ wypełniacza jako zastrzyk depot do mięśnia okrężnego ust w miejscu połączenia czerwieni z błoną śluzową po każdej stronie linii środkowej. Miejsce iniekcji powinno znaleźć się około jednej trzeciej odległości od linii środkowej do jamy ustnej.

Krok piąty - podparcie kątów ust. W tym wypadku umieszczamy wypełniacz o objętości $\sim 0,1 \mathrm{~cm}^{3}$ w najbardziej bocznym aspekcie dolnej wargi skórnej, aby zapewnić podparcie w górę. Igłę wprowadza się w węzeł mięśniowy kąta ust na głębokość ok. $1 \mathrm{~mm}$, wprowadzając wypełniacz odśrodkowo. Ta technika wymaga bardzo powierzchownego umieszczenia wypełniacza HA. Staramy się uniknąć powikłania wynikającego z powierzchownej implantacji wypełniacza jak niebieskawe zabarwienie skóry, znane jako efekt Tyndalla. Jeżeli na położenie ust wpływają nadmierne ruchy mimiczne twarzy zwiększające aktywność mięśnia obniżacza kątów ust, osiągnięcie pozytywnego efektu może wymagać kilku zabiegów. Ewentualnie można rozważać podanie toksyny botulinowej typu A, w przypadku nadmiernej aktywności mięśnia obniżacza kątów ust [13].

Krok szósty: Korekta fałdów nosowo-wargowych. Fałd nosowo-wargowy rozciąga się od bocznej części skrzydełka nosa do kąta ust. Należy zdeponować ok. 0,1 $\mathrm{cm}^{3}$ wypełniacza w górnej części nosowo-wargowej techniką głębokiej podśluzówkowej iniekcji. Trzeba zachować ostrożność w rejonie skrzydełek nosa, gdzie powierzchownie przebiega tętnica kątowa [14, 15]. Najlepiej materiał wstrzykiwać przyśrodkowo do linii bruzdy, aby zapobiec tworzeniu się grudek bocznie. Wypełnianie fałdu od strony bocznej może spowodować jego pogłębienie, a zbyt powierzchowne podanie tworzenie się grudek. Efekt powinien zredukować widoczność fałdu w spoczynku, natomiast podczas ruchów powinien być on widoczny [10].

\section{Opieka po iniekcji}

Można zastosować chłodne okłady, aby zminimalizować obrzęk i siniaki. Pacjentom należy zalecić unikanie ASA (kwas acetylosalicylowy), NLPZ (niesterydowe leki przeciwzapalne) i innych leków związanych ze wzrostem ryzyka krwawienia. Jeśli przepisano leki przeciw HSV I, należy kontynuować zgodnie z zaleceniami lekarza. Ponieważ KH są hydrofilowe, przyciągają wodę $z$ otoczenia tkanki i dodatkowo zwiększają objętość tkanek. Poza tym, czego można się jeszcze spodziewać po zabiegu to znaczący obrzęk cynaderki w bezpośrednim okresie pooperacyjnym.

Dla tych pacjentów, którzy mają wyraźną "szminkę promieniową" w skórnej części górnej wargi, dodatkowo konieczne może być leczenie toksyną botulinową. Należy zachować ostrożność, aby nie używać wypełniacza o wysokiej gęstości; mięsień okrężny ust to zwieracz i jego ciągła praca może spowodować zlepianie się solidnych wypełniaczy. Może to skutkować tworzeniem guzków i migracją produktu. Lepiej jest zastosować mniej lepki wypełniacz.

Klasyfikację powikłań zabiegów z użyciem wypełniaczy można podzielić według stopnia nasilenia (łagodne, umiarkowane, ciężkie), charakteru (powikłania alergiczne, naczyniowe, infekcyjne) lub według czasu wystąpienia (natychmiastowe, wczesne lub późne). Natychmiastowe (do 24 godzin po iniekcji) i wczesne (24 godziny do 4 tygodni po iniekcji) powikłania obejmują wybroczyny, obrzęk, infekcje, wybuch opryszczki, guzki i zaburzenia naczyniowe. Późne i opóźnione (więcej niż 4 tygodnie po wstrzyknięciu) obejmują wybroczyny, obrzęk, przebarwienia skóry, infekcje, tworzenie guzków i przemieszczenie materiału. Późne powikłania są podobne do tych obserwowanych w fazie początkowej i wczesnej, ale często ich przebieg jest bardziej przewlekły i przedłużający się [9].

\section{Cel pracy}

Usta należą do obszaru, którym zajmuje się lekarz dentysta i jego obowiązkiem jest ocena wyglądu i kondycji warg. Leczenie stomatologiczne, szczególnie z zakresu ortodoncji i protetyki stomatologicznej, powoduje poprawę wyglądu ust. Niestety często zdarza się, że po przeprowadzeniu leczenia lekarz dentysta lub pacjent widzą potrzebę poprawy wyglądu ust. W celu odbudowy naturalnych rysów ust u dojrzałych pacjentów oraz poprawy proporcji warg u młodych kobiet najczęściej stosuje się mało inwazyjne metody z zastosowaniem wypełniaczy. 
Głównym celem pracy jest przybliżenie podstawowych zasad wykonywania zabiegu korekty ust przez lekarza dentystę rozpoczynającego wykonywanie zabiegów z zakresu medycyny estetycznej.

\section{Materiał i metody}

Wszystkie zabiegi wykonano w Zakładzie Stomatologii Zintegrowanej Pomorskiego Uniwersytetu Medycznego w Szczecinie w ramach studiów podyplomowych - Medycyna estetyczna twarzy. Zabiegom poddano dwie kobiety w różnym wieku, które miały je przeprowadzane po raz pierwszy. W obu przypadkach przeprowadzono szczegółowy wywiad lekarski, badanie przedmiotowe, wykonano dokumentację fotograficzną (zdjęcia z profilu i en face) i uzyskano zgodę na wykonanie zabiegów oraz wykorzystanie fotografii ich twarzy w publikacji. Pacjentki poinformowano o możliwości wystąpienia efektów niepożądanych oraz powikłań pozabiegowych. Zdjęcia wykonano cyfrowym aparatem fotograficznym bez lampy błyskowej. Fotografie zarówno przed, jak i bezpośrednio po zabiegu zostały wykonane $w$ tym samym pomieszczeniu, w stałym oświetleniu przy użyciu tego samego trybu automatycznego aparatu.

U pierwszej pacjentki lat 32 wykonano zabieg modelowania ust, opierając się na podstawowych etapach poprawiających kształt i proporcje warg techniką 6 kroków z wykorzystaniem 1,2 ml kwasu hialuronowego. Druga pacjentka lat 65 miała widoczne oznaki starzenia wraz z silnie zaznaczonymi zmarszczkami palacza. $U$ tej pacjentki zastosowano techniki łączone, najpierw poprawiono definicję i objętość warg techniką sześciu kroków, z pominięciem pierwszego (pacjentka miała całkowicie zatarte kolumny filtrum). W tym celu wykorzystano $1 \mathrm{ml}$ kwasu hialuronowego. Po wypełnieniu i naturalnym odmłodzeniu ust, w odstępie 6-tygodniowym zastosowano neuromodulator Botox firmy Allergan (Ireland, Dublin) do spłycenia zmarszczek występujących w dolnym piętrze twarzy. Do procedur u obu pacjentek wykorzystano kwas hialuronowy średniej gęstości $23 \mathrm{mg} / \mathrm{ml}$ sodium hyaluronate $z$ lidokainą 0,3\% PRINCESS Filler Lidocaine firmy Croma Pharma (Austria, Leobendorf). Iniekcje wykonano małą igłą o rozmiarze 30G. Przygotowanie do zabiegu obejmowało zmycie makijażu. Następnie do odkażania skóry twarzy zastosowano środek przeciwbakteryjny zawierający oktenidynę Octenisept (Schuelke\&Mayr, Niem- cy, Hamburg). Pacjentkom zalecono, aby do 2 dni po iniekcji wypełniacza unikały gorących pryszniców, sauny, gorących potraw i napojów oraz ciężkich ćwiczeń.

\section{Wyniki badań}

Ocenę efektów zabiegów przeprowadzono na podstawie porównania fotografii wykonanych przed oraz bezpośrednio po zabiegu. Pacjentki były bardzo zadowolone z poprawy wyglądu, a efekt był widoczny natychmiast po zabiegu. Obserwowano minimalny ból i niewielkie zaczerwienienie punktów wejścia igły, bez siniaków, krwawień, obrzęków, swędzenia lub poważnych powikłań, takich jak infekcja, martwica, odbarwienie, grudki lub ziarniniak. U obu pacjentek uzyskano efekt odmłodzenia ust, stały się one pełniejsze i bardziej wyraźne. U młodszej pacjentki zarówno stosunek wysokości jak i objętości wargi dolnej i górnej zbliżył się do „złotej proporcji” (ryciny 1 i 2). U starszej pacjentki lepszy efekt uzyskano w zakresie poprawy stosunku objętości wargi dolnej do górnej (ryciny 3 i 4).
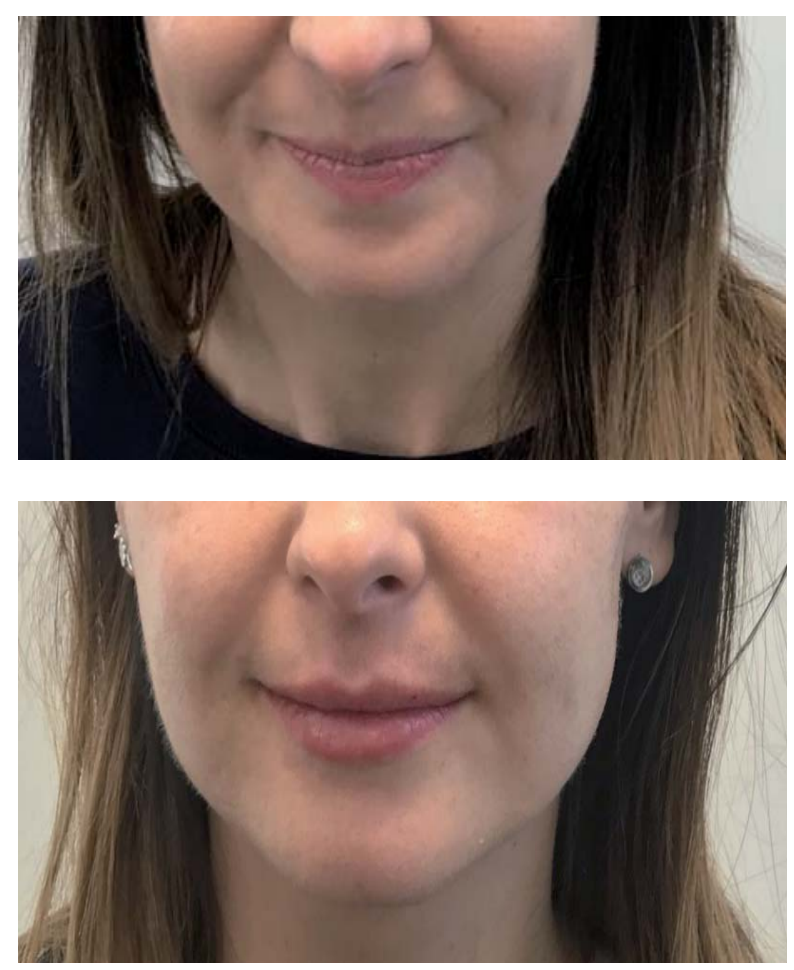

Rycina 1. Pacjentka 1. przed zabiegiem i po zabiegu. Fotografia własna

Figure 1. Patient 1 before and after treatment. Own photography 

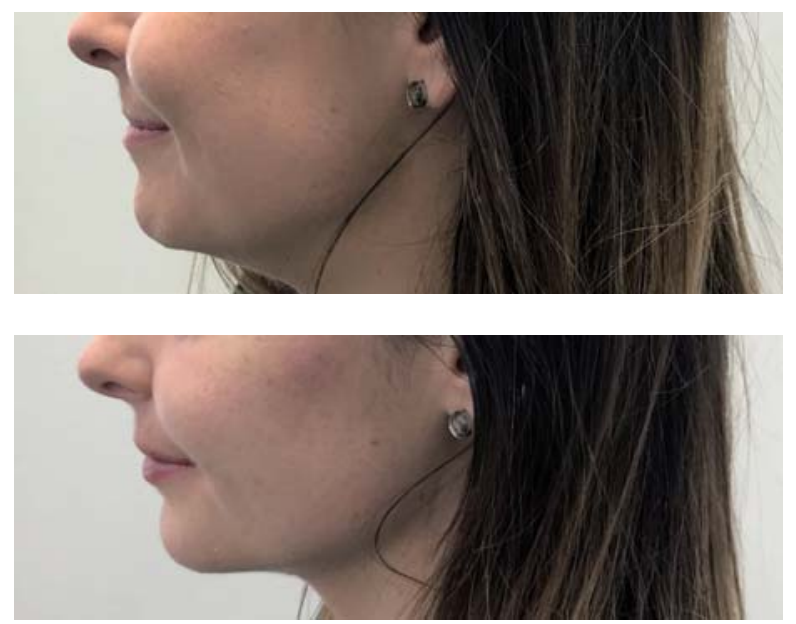

Rycina 2. Pacjentka 1. przed zabiegiem i po zabiegu profil. Fotografia własna

Figure 2. Patient 1 before and after treatment - profile. Own photography
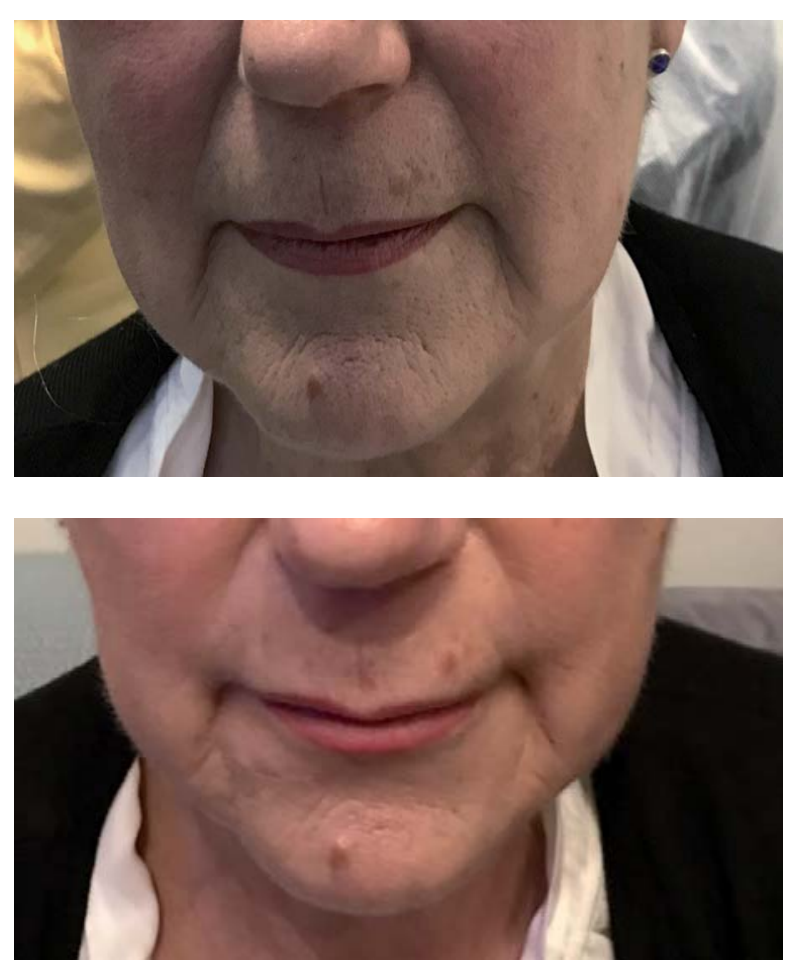

Rycina 3. Pacjentka 2. przed zabiegiem i po zabiegu. Fotografia własna

Figure 3. Patient 2 before and after treatment. Own photography

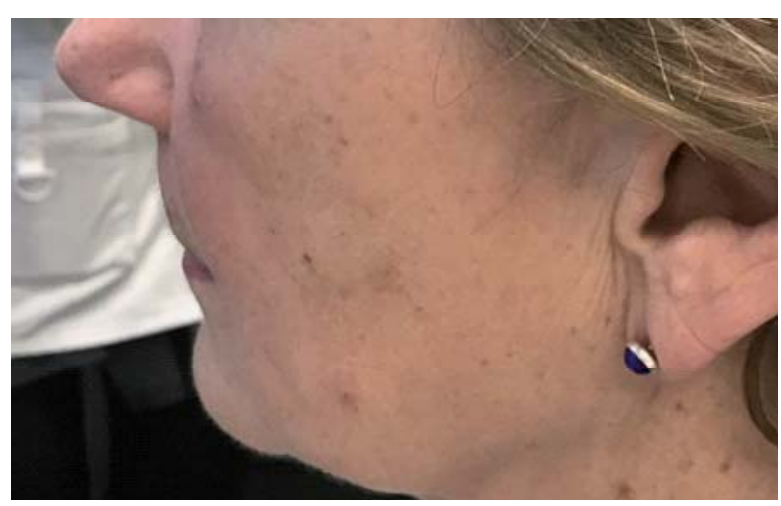

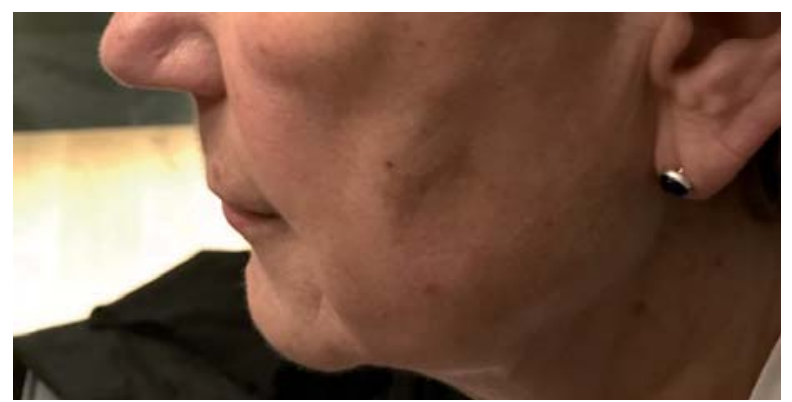

Rycina 4. Pacjentka 2. przed zabiegiem i po zabiegu profil. Fotografia własna

Figure 4. Patient 2 before and after treatment - profile. Own photography

\section{Dyskusja}

Badania antropometryczne wykazały, że szersze i pełniejsze usta w stosunku do szerokości twarzy, a także większa wysokość cynobru przyczyniają się do określania atrakcyjności kobiecej. Opisano różnorodne techniki powiększania warg (np. lifting warg, powiększanie błony śluzowej), jak i techniki wypełniania (np. wypełniacze do wstrzykiwań, transfer tłuszczu, implanty). Obecnie wypełniacz z kwasu hialuronowego stanowi główny środek stosowany w korekcji warg.

Celem korekcji górnej wargi jest artystyczne stworzenie formy, która harmonizuje z unikalnymi rysami twarzy pacjenta i uwzględnia jego wiek. Celem korekcji dolnej wargi jest stworzenie objętości i konturu cynobru. Lekarz musi ustalić odpowiednie wytyczne i oczekiwania pacjenta do powiększenia w stosunku do normalnych proporcji warg, aby uniknąć tzw. hiperkorekcji. Istnieje zatem potrzeba określenia podstawowych zasad, którymi może się kierować początkujący lekarz dla otrzymania atrakcyjnych i estetycznych rezultatów. Przed zabiegiem powinniśmy wysłuchać pacjenta i upewnić się, czy jego żądania są uzasadnione. Nierealne oczekiwania mogą być przyczyną zaburzeń dysmorficznych. W takich przypadkach nie powinniśmy się bać odmówić leczenia.

W ramach zabiegu modelowania ust można: powiększyć usta, troszkę wywinąć usta, odtworzyć granicę pomiędzy czerwienią a skórą, wyrównać asymetrię, przywrócić proporcje, unieść kąciki [16].

Za pomocą kwasu hialuronowego możemy poprawiać kształt, spłycać zmarszczki, wypełniać bruzdy oraz odmładzać. Co ważne, zabiegi te są mało inwazyjne, bezpieczne i dają w pełni odwracalne w skutkach efekty, a ich popularność stale rośnie. Spodziewane przemijające efekty powiększenia warg po zabiegu obejmują obrzęk, zasinienie i wybroczyny. Powikłania są niezwykle rzadkie i obejmują guzki i grudki, które można masować lub rozpuszczać za pomocą zastrzyków z hialuro- 
nidazy. Reaktywacji opryszczki można zapobiec, stosując doustne leki przeciwwirusowe (acyklowir, famcyklowir lub walacyklowir) [13]. Najpoważniejsze powikłania mają charakter naczyniowy, mogą prowadzić do martwicy tkanek i utraty wzroku. Jednak dotyczą one częściej autologicznych przeszczepów tłuszczu (47,9\%) niż kwasu hialuronowego $(23,5 \%)$. Beleznay i wsp. w swoich doniesieniach zalicza fałd nosowo-wargowy do miejsc o większym ryzyku powikłań $(13,3 \%)$, po okolicy nosa $(25,5 \%)$ i glabelli $(38,8 \%)$ [17]. W wypadku podania materiału do tętnicy następuje silny ból i zblednięcie okolicy. Nie ma jeszcze żadnych ograniczeń ani wytycznych co do tego, jak głęboko i ile substancji można wstrzyknąć w obszar okołowargowy. Chiu i wsp. propagują wypełnianie ust według zasady „mniej znaczy więcej”, co może być najważniejszym czynnikiem uzyskania naturalnego efektu [18]. Natomiast istnieją nowe doniesienia wypełniania okolicy ust za pomocą kaniuli, co wymaga większego doświadczenia i wprawy od operatora. Potwierdzono, iż efektem pracy z kaniulą są mniejsze obrzęki i siniaki [2]. Częste powikłania okolicy okołoustnej po powiększeniu KH, takie jak krwiak i ból, mogą wystąpić w pierwszych dniach po wstrzyknięciu, ale ciężkie krwawienie, uszkodzenie nerwów, choroba zakrzepowo-zatorowa występują rzadko [16]. Jeśli ostrzyknięte zostaną małe gruczoły ślinowe, mogą wystąpić torbiele retencyjne i zapalenie sialadenitis [20]. W przypadku jakichkolwiek wątpliwości korzystne byłoby zlokalizowanie kluczowych struktur i umiejscowienie wstrzykniętego materiału po iniekcji za pomocą ultradźwięków, aby uniknąć poważnych komplikacji [3].

Pacjentom zgłaszającym się w celu modelowania ust należy doradzić ocenę okolicy wokół ust. $W$ razie potrzeby należy równolegle wykonać zabiegi w obrębie struktur przyległych w celu osiągnięcia estetycznego efektu korekcji w zakresie dolnego piętra twarzy.

\section{Wnioski}

1. Zabiegi z zastosowaniem kwasu hialuronowego są skuteczną metodą korekty kształtu ust.

2. Techniką sześciu kroków można bezpiecznie wykonywać zabiegi w obrębie szeregu struktur anatomicznych, w tym w zakresie filtrum, łuku Kupidyna, czerwieni wargowej, granicy czerwieni wargowej, kątów ust oraz kolumn rynienki podnosowej.

3. Zabiegi te nie wymagają specjalnego przygotowania pacjenta, są dobrze tolerowane, pozwalają uzyskać naturalny, natychmia- stowy efekt i nie wymagają okresu rekonwalescencji.

\section{Oświadczenia}

Oświadczenie dotyczące konfliktu interesów

Autorzy deklarują brak konfliktu interesów

w autorstwie oraz publikacji pracy.

\section{Źródła finansowania}

Autorzy deklarują brak źródeł finansowania.

\section{Piśmiennictwo}

[1] Werschler WP, Fagien S, Thomas J, Paradkar-Mitragotri D, Rotunda A, Beddingfield FC. Development and validation of a photographic scale for assessment of lip fullness. Aesthet Surg J. 2015;35(3):294-307.

[2] Kar M, Muluk NB, Bafaqee SA, Cing C. Is it possible to define the ideal lips? Acta Otorhinolaryngol Ital. 2018;38(1):67-72.

[3] Gupta A, Miller PJ. Management of lip complications. Facial Plast Surg Clin North Am. 2019;27(4):565-570.

[4] Stolic D, Jankovic M, Draskovic M, Georgiev S, Stolic $M$. The surgical lips deformity corrected with hyaluronic fillers: A case report. Open Access Maced J Med Sci. 2015;3(3):423-425.

[5] Sahan A, Tamer F. Four-point injection technique for lip augmentation. Acta Dermatovenerologica. 2018;27:71-73.

[6] Fallacara A, Manfredini S, Durini E, Vertuani S. Hyaluronic acid fillers in soft tissue regeneration. Facial Plast Surg. 2017;33(1):87-96.

[7] Sarnoff DS, Gotkin RH. Six steps to the "perfect" lip. J Drugs Dermatol. 2012;11(9):1081-1088.

[8] Heydenrych I, Kapoor KM, De Boulle K, Goodman G, Swift A, Kumar N, Rahman E. A 10-point plan for avoiding hyaluronic acid dermal filler-related complications during facial aesthetic procedures and algorithms for management. Clin Cosmet Investig Dermatol. 2018;11:603-611.

[9] Borzacchiello A, Russo L, Malle BM, SchwachAbdellaoui K, Ambrosio L. Hyaluronic acid based hydrogels for regenerative medicine applications. Biomed Res Int. 2015;2015:871218.

[10] Fallacara A, Baldini E, Manfredini S, Vertuani S. Hyaluronic acid in the third millennium. Polymers. 2018;10(7):701-736.

[11] Kaya G, Kaya A, Saurat JH. Induction of hyalurosome by topical hyaluronate fragments: results in superficial filling of the skin complementary to hyaluronate filler. injections. Dematopathology. 2019;6:45-49.

[12] Khunmanee S, Jeong Y, Park H. Crosslinking method of hyaluronic-based hydrogel for biomedical applications. J Tissue Eng. 2017;8:1-16.

[13] Woodward J, Khan T, Martin J. Facial filler complications. Facial Plast Surg Clin North Am. 2015;23(4):447-458.

[14] Greene RM. Comparing the use of injectable fillers for the youthful lip and the more mature lip. Facial Plast Surg. 2019;35(2):134-139.

[15] Luthra A. Shaping lips with fillers. J Cutan Aesthet Surg. 2015;8(3):139-142. 
[16] Hotta TA. Lip enhancement: physical assessment, injection techniques, and potential adverse events. Plast Surg Nurs. 2018;38(1):7-16.

[17] Beleznay K, Carruthers JD, Humphrey S, Jones D. Avoiding and treating blindness from fillers: A review of the world literature. Dermatologic Surg. 2015;41(10):1097-1117.

[18] Chiu A, Fabi S, Dayan S, Nogueira A. Lip injection techniques using small-particle hyaluronic acid dermal filler. J Drugs Dermatol. 2016;15(9):1076-1082.

[19] Chiang YZ, Pierone G, Al-Niaimi F. Dermal fillers: pathophysiology, prevention and treatment of complications. J Eur Acad Dermatol Venereol. 2017;31(3):405-413.

[20] Rohrich RJ, Bartlett EL, Dayan E. Practical approach and safety of hyaluronic acid fillers. Plast Reconstr Surg Glob Open. 2019;7(6):e2172.
[21] Vent J, Lefarth F, Massing T, Angerstein W. Do you know where your fillers go? An ultrastructural investigation of the lips. Clin Cosmet Investig Dermatol. 2014;20(7):191-199.

Zaakceptowano do edycji: 28.06 .21 Zaakceptowano do publikacji: 29.09.21

\section{Adres do korespondencji:}

Zakład Stomatologii Zintegrowanej PUM w Szczecinie

al. Powstańców Wlkp. 72

70-111 Szczecin

tel.: 914661690

e-mail: katgro@pum.edu.pl 